\title{
Students with Emotional Disorders: Are Primary Education Teachers Prepared to Teach Them?
}

\author{
Saríah López-Fierro \\ ${ }^{1}$ DII, Universidad Técnica Federico Santa María, Chile \\ * Corresponding Author: sariah.lopez@sansano.usm.cl
}

Citation: López-Fierro, S. (2020). Students with Emotional Disorders: Are Primary Education Teachers Prepared to Teach Them? International Journal of Childhood Education, 1(1), 32-41. https://doi.org/10.33422/ijce.v1i1.12

\begin{abstract}
Emotional disorders, mainly manifested in depression and anxiety, are challenges that affect a person's feelings, thoughts, and behaviour. In children, different efforts have existed to prevent emotional disorders that, depending on the case, can occur at different stages of academic development. Nevertheless, these attempts have proven to be ineffective among elementary education students. Since most children spend a large part of their time in schools, various authors argue that academic institutions are the prime location for detecting mental disorders as early as possible, in order to effectively guide students to adequate health services. However, are our teachers prepared for it? Are our academic institutions prepared for it? The close relationship between mental health and the process of learning in schools, justifies investigating that may reveal a real, emergent and unattended problem. These results might raise awareness in the academic society about a topic that should be considered at the moment of planning classes. This paper intends to justify further research on the preparation of teachers to deal adequately with students with mental disorders. In order to do so, it has been gathered different theories that show a problem that needs to be addressed. Besides, interviews applied to professors from elementary levels of Chilean schools included in this work, support this theory.

Key words: emotional disorders; children; teachers ' preparedness; teaching; primary education
\end{abstract}

\section{Introduction}

The learning process from sociocultural theory includes four basic factors: cognitive development, which varies from one person or one culture to another; social interaction, which enables cognitive growth or the construction of knowledge through guided learning within the Proximate Development Zones (Rico, 2009); socialization, which allows communication, by the construction of individual psychological processes, such as social speech; and exchange with adults who transmit cognitive "tools" through culture, which "tools" can be internalized by the learner. Correlated to the above, it is also argued that learning passes through three inseparable dimensions: cognitive, motivational and social (Bourgeois, 2009).

Learning also involves three processes, which could be presented simultaneously: acquiring new information or improving existing information, transforming or manipulating knowledge to adjust it to new challenges, and evaluating the way in which we process information (Bruner, 1960). The acquisition, transformation and evaluation imply an accumulation of "understood experiences" which are closely related to what people are and feel (Bisquerra, 2005), therefore, it must include the individual's predisposition for learning, in order to be acquired (Bruner, 1960). In other words, in the classroom, many times, achieving the learning objectives depends more on emotions than on reasons. Therefore, you don't learn what you don't want or what doesn't motivate you; 
and if something does not motivate, it is because it may not generate positive emotions (García, et. al., 2012).

Consequently, after involving interaction, exchange, socialization, predisposition, etc., in the learning process, it has been evident that emotions and feelings influence the acquisition of knowledge. Thus, everything we do, think, imagine or remember is possible when the rational and emotional part of the brain work together (Martínez, 2009). Through this way, feelings imply a resignification of events, which allows us to observe how cognition and emotion affect each other. (García, et. Al., 2012).

With the aforementioned, and highlighting the important participation of emotions in learning, it is possible to infer that teaching children with emotional disorders involves different challenges.

\section{Emotional Disorders}

Emotional disorders are among the most common psychiatric disorders diagnosed in children and adolescents; being also identified as the main cause of disease among young people (Gore, et. al., 2011). They are associated with being responsible for several issues, such as: physical health, chemical substance abuse, smoking, difficulties in establishing family and social relationships, and educational challenges (Essau, et. Al., 2000; Horowitz, et. Al., 2006). Two types of emotional disorders generally related to these problems are, mood disorders or better identified as depression, and anxiety (Finning, et. Al., 2017; Green, et. Al., 2005).

In 2014, depression was recognized by WHO (World Health Organization), as the primary factor of global disability, affecting more than 350 million individuals (Ramnerö, et. Al., 2016). It involves multiple emotional disorders, such as, irritable mood (more common among young people and children); little interest or pleasure in all or almost all activities; psychomotor agitation; fatigue or loss of energy; low self-esteem, feeling of little personal worth; excessive or inappropriate feeling of guilt; poor ability to think and concentrate, or indecisiveness; exaggerated rest periods, or isolation; frequent expression of discomfort or complaints; deep reflection of personal conditions; recurrent thoughts of death, which not only include the fear of dying (APA, 2013; Paranhos, 2009; Lewinsohn, et. al., 1976; Martell, et. al, 2010; Ramnerö, et. al., 2016). These disorders maintain heterogeneous clinical presentations due to their duration and severity (Ramnerö, et. Al., 2016); and although they can be similar to symptoms that are also observed in people not diagnosed with depression, they are differentiated by their frequency (Ferster, 1973).

Data reveal that the rate of depression found in adolescents fluctuates between $3 \%$ and $9 \%$, with a cumulative prevalence of $20 \%$ until the end of adolescence (Callahan et. Al., 2012); thus becoming the main cause of mortality among young people, due it is associated with interpersonal difficulties, deficits in academic performance, drug use, aggressive behaviors, inappropriate sexual activity, and suicidal behavior (Brochado \& Brochado, 2008).

Meanwhile, anxiety constitutes one of the most frequent psychological problems, whose rate of affectation fluctuates between $13-15 \%$ of the world population (Caballo et. Al, 2000). Anxiety might be identified by the uncontrollable feeling of being faced with possible threats (Arenas et. Al., 2009). It may be characterized in different ways, such as: anguish crisis, which is limited in two types, expected and unexpected crises; panic disorder and agoraphobia, which includes dealing with fear and avoidance; social anxiety or social phobia; obsessive-compulsive disorder; selective mutism; excessive worry; post-traumatic stress disorder, acute stress disorder; unspecified anxiety disorders; among others (Feliú, 2014; APA, 2013). 


\section{Children with Emotional Disorder}

According to some publications, in children there is a close relationship between these two types of disorders (Eason, et al., 1985; Norvell, et. Al., 1985). For this reason, in infants, depression and anxiety are identified as "internalization symptoms (or problems)" (Tandon, et. Al., 2009).

Depression in children only began to be studied in the 1980s (Kaslow, et. Al., 1984; Kovacs, 1983, 1985; Nolen-Hoeksema, et. Al., 1986; Seligman et. Al., 1984). And although it is recognized that depression is usually underdiagnosed at a young age (Queiroz, et. Al., 2016), it has been published that about 5\% of children suffer from it at some point (AACAP, n.d.). Because most of the time children do not have the resources to recognize their emotions and thoughts, diagnosing depression in them has been found to be a complex task. Therefore, the most appropriate way to identify depressive symptoms is by being observed by those who are part of their daily activities, such as parents and teachers (Cruvinel, et. Al., 2009).

The association between childhood depression and academic performance has been evaluated by several authors (Palladino, et. Al., 2004; Cruvinel, et. Al., 2003; Cruvinel, et. Al., 2004). Depression can affect school performance, to the point of impairing children's self-efficacy, leading them to think that they are not capable of learning, since they do not believe in their own performance (Cruvinel, et. Al., 2004). Among the investigations carried out, it has been concluded that low academic performance and being judged as incompetent is also related to depression (Rodríguez, et. Al., 1989; Blechman, et. At, 1986). This was reflected in a study of aptitude and achievement, in which children diagnosed with depression, although with similar abilities compared to their other classmates, showed lower competencies and a lower academic average (Davis \& Connell, 1985).

Another common action in children with depression that contributes to poor academic performance is reducing school attendance. Research has characterized non-attendance at schools in two possible causes. First, rejecting school after finding emotional stress in it, along with reporting somatic symptoms, such as headaches, stomach problems and fatigue are common in children with emotional disorders (Bernstein et. al., 1997). Second, lack of interest in school or antisocial behaviour (Fremont, 2003), supporting the argument that depressed people tend to withdraw from social interactions (Lewinsohn, 1974).

Since most children spend a large part of their time in school, various authors argue that academic institutions are the prime location for preventive intervention aimed at detecting mental disorders as early as possible, and thus referring students to health services or mental health institutions (Santos, et al., 2014; Finning, et. al., 2017).

However, it is estimated that approximately $80 \%$ of children fail to access effective treatment, since they were not correctly diagnosed (Collins, et. Al., 2004; Ford, et. Al., 2007). One cause could be that no distinction is made between emotional and learning disorders at the moment of examining students (Rodrigues, et. Al., 2016). When children with learning disabilities, for example, have a performance below the average of their peers, this experience leaves them emotionally affected (Rodríguez, et. Al., 1989). And, since emotional factors are not addressed in learning disability programs, depression and anxiety in children tends to be more pronounced. (Rodríguez, et. Al., 1989). Therefore, children with stress, negative academic experiences, lack of attention, inadequate behaviour or anxiety disorders have a high probability of falling into depression (AACAP, n.d.).

Consequently, during the learning process, the most stressful events are generally related to school activities, causing this chain (negative emotions that affect the performance of children in schools, and circumstances of a school environment that generate depression), a vicious cycle of emotional disorders that could be potentiated (Rodríguez, et. al., 1989). 


\section{Chilean Context}

In Chile, some public programs have been organized to support families for preventing suicides or depression (MINSAL, 2013a).

At the educational level, teachers have been given instruments that contribute with abroad concerns about mental health (MINSAL, 2013b; Rojas M. I., n.d.), or that may improve with the students' attention deficit (MINEDUC, 2009). But none of these efforts are focused on fully supporting those with emotional disorders. As a consequence, they are not an efficient guide, and delegate to the educational institutions and teachers the complete responsibility of responding to this reality.

For the purpose of justifying further research after getting glimpses of the Chilean context, it was conducted semi-structured interviews (see Table 1 as reference for the list of the questions) to five active professors who are master's students from the Department of Education of the Universidad Católica de Chile, and an active professor from the same department. Besides, with the aim of counteracting and comparing the results in different contexts, variety was sought in the type of teaching and the environment in which they teach their classes.

Table 1.

Semi-Structured Interview Applied

1. Can you tell the differences between a student who has learning problems with one who has emotional disorders?

$$
\text { Yes } \square \quad \text { No } \square
$$

2. Do you have any kind of instruction on how to respond in your classes when you perceive some trait of emotional disorders among your students?

$$
\text { Yes } \square \quad \text { No } \square
$$

3. Does the school where you work apply some kind of inventory to students to determine if they have emotional disorders?

$$
\text { Yes } \square \quad \text { No } \square \quad \text { I don't know } \square
$$

4. If the answer was yes, how often are these inventories applied?

Sometimes during the school year $\square$

Once every semester $\square$

Once every year $\square$

There is no set time $\square$

I don't know $\square$

5. During your teaching process, have you detected any of your students with emotional disorders?

Yes $\square \quad$ No $\square$

6. In your classroom, have you identified students with emotional disorders?

Yes, what did you identify?

No $\square$

I'm not sure, why?

7. Have you changed / modified / adapted your class when you have detected someone with emotional disorders?

\section{Yes $\square \quad$ No $\square$}

8. Do you think it is justifiable for a class to adapt / change for a child who has been identified with an emotional disorder?

Yes $\square \quad$ No $\square$

9. Do you consider that students with emotional disorders affect the teaching process?

Yes $\square \quad$ No $\square \quad$ I don't know $\square$

10. What are the main challenges in teaching that a teacher faces when he/she has among his/her students, children or young people with emotional disorders?

11. What do you consider to be the main challenges in the learning process for children with emotional disorders?

In order to prevent teachers from confusing the symptoms of emotional disorders with signs of learning problems as possible, before answering the questionnaire, definitions were given to 
the professors (see Table 2). Along with the survey, it was intended to make the interviewed to analyse the observed symptoms of learning disabilities and emotional disorders, after remembering signs presented by their own students.

Table 2.

Definitions of Learning Disabilities and Emotional Disorders

Learning disabilities are disorders that affect the ability to understand or use spoken or written language, do mathematical operations, coordinate movements, or direct attention (NIH, 2016).

Emotional disorders are among the most common psychiatric disorders diagnosed in children and adolescents (Gore et. Al., 2011); they are diagnosed in different ways; but they are generally related to mood disorders or depression, and anxiety (Finning, et. al., 2017) (Green et. al., 2005)

The semi-structured interview intended to gather the level of preparation of teachers regarding the focus of this research. Answers allowed to infer if their procedures were empirical, reactive, or formally supported. Besides, some questions referred to the congruence of "knowing what to do", "wanting to do" and "being able to do", based on the personal point of view of the teacher. For example, when a teacher responded that emotional disorders in students did affect the teaching process, but it was not considered it justifiable to change her class, and did not modified it for these reasons; it was be inferred that their class was affected and there was not a correct learning process.

Average age of respondents was 30 years old, while the postgraduate professor was over 60 years old. All of them have teaching degrees and have taught to high and low economic groups. All the interviewees are or have taught children. Two teachers thought that low economical resources put children in "vulnerability" status, although they do not relate this vulnerability with any tendency for acquiring emotional disorders.

Except for one, all the interviewees did not have any kind of instructions in emotional disorders, although three of them considered being able to distinguish children with depression or anxiety, supporting their diagnosis with the "discouragement shown in children's faces". All the respondents have detected students with emotional problems after noticing in them: impulsivity, insecurity, outbursts of anger or frustration, emotional imbalance, dysregulation, negativity, frustration and anxiety about failure, among others.

Two of the interviewees are not sure if their institutions are employing any kind of measure for helping children with mental disorders; one of them even shared, that after facing and reporting a crisis with a student, she was told by her supervisor that "it was common for this girl to defecate in classes", leaving her to handle the challenge by her own.

Table 3.

Challenges faced during the teaching process

\begin{tabular}{|c|c|}
\hline \multicolumn{2}{|c|}{ Teaching students with emotional disorders } \\
\hline Challenges for teachers & Challenges for students w/ e.d. \\
\hline $\begin{array}{l}\text { - } \text { Understand them } \\
\text { - } \text { Adjust to their needs } \\
\text { - } \text { Identify what happens to them } \\
\text { - } \text { Motivate them to work with other children. } \\
\text { - } \quad \text { Get them interested in the class } \\
\text { - } \quad \text { Watch over their progress } \\
\text { - } \quad \text { Watch over the class in order to not get affected } \\
\text { - } \quad \text { Behavioural management } \\
\text { - } \quad \text { Encourage them, without neglecting others }\end{array}$ & $\begin{array}{l}\text { - } \text { Connect with what they are doing. } \\
\text { - } \text { Identify among themselves if they have } \\
\text { - } \quad \text { pervasive learning or emotional disorders } \\
\text { - } \quad \text { Avoid dependence on adults. } \\
\text { - } \quad \text { Feeling off } \\
\text { - } \quad \text { Guarantee optimal environment. } \\
\text { - } \quad \text { Frustration to intolerance } \\
\text { Lack of attention }\end{array}$ \\
\hline
\end{tabular}

Three of interviewees have adjusted their classes for helping, in some way, children who they have identified with emotional disorders. The other three considered that more than changing 
the program or activities, the main challenge is to integrate them to a work group, in order to achieve balance in the class, thus "helping these students, without neglecting the rest". However, all professors, except for one, admitted that a student with external symptoms of emotional disorders affects the teaching process.

One of the interviewees shared: "I think this has increased over time. We are living in a generation with depression".

The interviews provided context to the research, for instance: the challenges that the teachers and students with emotional disorders (see Table 3) faced during the learning process, supporting the importance of doing further investigations about the teachers' preparedness.

\section{Conclusions}

Despite being theoretically justified, and identified by all the interviewees that emotional disorders are a negative factor in the teaching process, no studies have been found that show the real situation of teachers, educational institutions and, it is inferred that neither of the government, to specifically address these types of disorders.

And considering that according to the World Health Organization (WHO), 17\% of Chileans suffer from depression (El Mostrador, 2016), it could be inferred that, since there is no environment prepared to respond to the general needs of students with this type of disorder, we could perhaps find in the near future a generation with a high percentage of people with academic and social limitations.

The importance of conducting an investigation that could present a real, emerging and unattended problem is supported. These results will finally make it possible to raise awareness in the academic society about a subject that should be considered in the planning of their classes, and discussions and solutions can be generated to fully address this limitation.

As a future work, it is intended to apply a survey to a significant sample of teachers, which results may permit the educational community to make decisions based on improving the academic experience for children with emotional disorders. In addition, with this work, I also intend to motivate other researchers to confirm or rule out that more preparation is needed to address children with depression within the learning process.

\section{Acknowledgment}

This work has been supported by DGIIP of the Universidad Técnica Federico Santa María, de Valparaíso-Chile.

\section{References}

AACAP - American Academy of Child and Adolescent Psychiatry (n.d.). Washington: American Academy of Child and Adolescent Psychiatry; Retrieved from https://www.aacap.org/aacap/families_and_youth/Resource_Centers/Depression_Resource _Center/Home.aspx

APA - American Psychiatry Association. (2013) Diagnostic and Statistical Manual of Mental disorders - DSM-5. 5 thed. Washington: American Psychiatric Association; 2013

Arenas, M. Carmen, \& Puigcerver, Araceli. (2009). Sex differences of anxiety disorders: Possible psychobiological causes. Escritos de Psicología (Internet), 3(1), 20-29. Retrieved 23 may 2019, from http://scielo.isciii.es/scielo.php?script=sci_arttext\&pid=S1989$38092009000300003 \& \operatorname{lng}=$ es\&tlng=en.

Bernstein, G. A., Massie, E. D., Thuras, P. D., Perwien, A. R., Borchardt, C. M., \& Crosby, R. D. (1997). Somatic symptoms in anxious-depressed school refusers. Journal of the 
American Academy of Child \& Adolescent Psychiatry, 36(5), 661-668. https://doi.org/10.1097/00004583-199705000-00017

Bisquerra, R. (2005). La educación emocional en la formación del profesorado. Revista Interuniversitaria de Formación del Profesorado, 19 (3). Retrieved from redalyc.uaemex.mx/pdf/274/27411927006.pdf

Blechman, E. A., McEnroe, M. J., Carella, E. T., \& Audette, D. P. (1986). Childhood competence and depression. Journal of Abnormal Psychology, 95(3), 223-227. https://doi.org/10.1037/0021-843X.95.3.223

Brochado, F., \& Brochado, A. (2008). Estudo da presença de sintomatologia depressiva na adolescência. Revista.

Bruner, J. (1960). El proceso de la educación. México: Unión Tipográfica Editorial HispanoAmericana.

Caballo, V., \& Mateos, P. (2000). El tratamiento de los trastornos de ansiedad a las puertas del siglo XXI. Psicología Conductual, 8(2), 173-215.

Callahan, P., Liu, P., Purcell, R., Parker, A., \& Hetrick, S. (2012). Evidence map of prevention and treatment interventions for depression in young people. Depression Research and Treatment, 2012(820735), 1-11. https://doi.org/10.1155/2012/820735

Collins, K. A., Westra, H. A., Dozois, D. J., \& Burns, D. D. (2004). Gaps in accessing treatment for anxiety and depression: challenges for the delivery of care. Clinical psychology review, 24(5), 583-616. https://doi.org/10.1016/j.cpr.2004.06.001

Cruvinel, M., \& Boruchovitch, E. (2003). Depressão infantil: uma contribuição para a prática educacional. Psicologia escolar e educacional, 7(1), 77-84. https://doi.org/10.1590/s1413$\underline{85572003000100008}$

Cruvinel, M., \& Boruchovitch, E. (2004). Sintomas depressivos, estratégias de aprendizagem e rendimento escolar de alunos do ensino fundamental. Psicologia em estudo, 9(3), 369378. https://doi.org/10.1590/s1413-73722004000300005

Cruvinel M. (2009) Correlatos cognitivos e psicossociais de crianças com e sem sintomas depressivos [tese]. Campinas (SP): Universidade Estadual de Campinas.

Davis, H. B., \& Connell, J. P. (1985). The effect of aptitude and achievement status on the selfsystem. Gifted Child Quarterly, 29(3), 131-136. https://doi.org/10.1177/00169862850 $\underline{2900306}$

Dobson, K. S., \& Dozois, D. J. A. (2004). The prevention of anxiety and depression: Promises and prospects. In D. J. A. Dozois \& K. S. Dobson (Eds.), The prevention of anxiety and depression: Theory, research, and practice (p. 283-295). American Psychological Association. https://doi.org/10.1037/10722-012

Eason, L. J., Finch, A. J., Jr., Brasted, W., \& Saylor, C. F. (1985). The assessment of depression and anxiety in hospitalized pediatric patients. Child Psychiatry and Human Development, 16, 57-64. https://doi.org/10.1007/bf00707770

El Mostrador. (2016). Altos índices de depresión y suicidios de niños en Chile levantan alerta de la OMS. Retrieved from https://www.elmostrador.cl/noticias/pais/2016/04/15/altosindices-de-depresion-y-suicidios-de-ninos-en-chile-levantan-alerta-de-la-oms/

Essau, C. A., Conradt, J., \& Petermann, F. (2000). Frequency, comorbidity, and psychosocial impairment of anxiety disorders in German adolescents. Journal of anxiety disorders, 14(3), 263-279. https://doi.org/10.1016/s0887-6185(99)00039-0 
Feliú, M. T. (2014). Los Trastornos de Ansiedad en el DSM-5. Cuadernos de medicina psicosomática y psiquiatria de enlace, (110), 62-69.

Ferster, C. B. (1973). A functional analysis of depression. American Psychologist, 28, 857-870

Finning, K., Moore, D., Ukoumunne, O. C., Danielsson-Waters, E., \& Ford, T. (2017). The association between child and adolescent emotional disorder and poor attendance at school: a systematic review protocol. Systematic reviews, 6(1), 121. https://doi.org/10.1186/s13643$\underline{017-0523-6}$

Ford, T., Hamilton, H., Meltzer, H., \& Goodman, R. (2007). Child mental health is everybody's business: The prevalence of contact with public sector services by type of disorder among British school children in a three-year period. Child and Adolescent Mental Health, 12(1), 13-20. https://doi.org/10.1111/j.1475-3588.2006.00414.x

Fremont, W. P. (2003). School refusal in children and adolescents. American family physician, 68(8), 1555-1560.

García Retana, J. Á. (2012). La educación emocional, su importancia en el proceso de aprendizaje. Educación, 36(1). https://doi.org/10.15517/revedu.v36i1.455

Gore FM, Bloem PJN, Patton GC, Ferguson J, Joseph V, Coffey C, Sawyer SM, Mathers CD. (2011) Global burden of disease in young people aged 10-24 years: a systematic analysis. Lancet. 2011; 377: 2093-102. https://doi.org/10.1016/s0140-6736(11)60512-6

Green H, McGinnity, Á., Meltzer, H., Ford, T., \& Goodman, R. (2005). Mental health of children and young people in Great Britain, 2004. H. Green (Ed.). Basingstoke: Palgrave Macmillan.

Horowitz, J. L., \& Garber, J. (2006). The prevention of depressive symptoms in children and adolescents: a meta-analytic review. Journal of consulting and clinical psychology, 74(3), 401. https://doi.org/10.1037/0022-006x.74.3.401

Kaslow, N. J., Rehm, L. P., \& Siegel, A. W. (1984). Social-cognitive and cognitive correlates of depression in children. Journal of abnormal child psychology, 12(4), 605-620. https://doi.org/10.1007/bf00916853

Kovacs, M. (1983). The Children's Depression Inventory: A self-rated depression scale for school-aged youngsters. University of Pittsburgh School of Medicine, Department of Psychiatry, Western Psychiatric Institute and Clinic.

Kovacs, M. (1985). The children's depression inventory (CDI). Psychopharmacol bull, 21, 995-998.

Lewinsohn, P. M. (1974). A behavioral approach to depression. Essential papers on depression, 150-72.

Lewinsohn, P. M., Biglan, A. \& Zeiss, A. M. (1976). Behavioral treatment of depression. In P. O. Davidson (Ed.), The behavioral management of anxiety, depression and pain (pp. 91146). New York: Brunner/Maze

Martell, C. R., Dimidjian, S. \& Herman-Dunn, R. (2010). Behavioral activation for depression: A clinician's guide. New York: Guilford Press

Martínez, C. (2009). Consideraciones sobre inteligencia emocional. La Habana, Cuba: Editorial Científico-Técnica. 
NIH - National Institutes of Health. (2016). Problemas de aprendizaje: National Institute of Neurological Disorders and Stroke (NINDS). Retrieved 1 junio, 2019, from https://espanol.ninds.nih.gov/trastornos/problemas_de_aprendizaje.htm

MINEDUC - Ministerio de educación de chile, et al. (2009). Déficit de Atención. Retrieved 7 June, 2019, from https://www.minsal.cl/portal/url/item/71e7a5ac9b1dfe dae04001011f010680.pdf

MINSAL - Ministerio de Salud (2013a). Programa nacional de prevención de suicidio. Retrieved 7 June, 2019, from https://www.minsal.cl/portal/url/item/7222754637 c08646e04001011f014e64.pdf

MINSAL - Ministerio de Salud (2013b). Depresión en personas de 15 años y más. Retrieved 7 June, 2019, from https://www.minsal.cl/portal/url/item/7222754637c08646e040010 11f014e64.pdf

Nolen-Hoeksema, S., Girgus, J. S., \& Seligman, M. E. (1986). Learned helplessness in children: A longitudinal study of depression, achievement, and explanatory style. Journal of personality and social psychology, 51(2), 435. https://doi.org/10.1037/0022$\underline{3514.51 .2 .435}$

Norvell, N., Brophy, C., \& Finch Jr, A. J. (1985). The relationship of anxiety to childhood depression. Journal of Personality Assessment, 49(2), 150-153. https://doi.org/10.1207/s15327752jpa4902_8

Palladino, P., Poli, P., Masi, G., \& Marcheschi, M. (2000). The relation between metacognition and depressive symptoms in preadolescents with learning disabilities: Data in support of Borkowski's model. Learning Disabilities Research \& Practice, 15(3), 142-148.

Paranhos, M. (2009). Estudo de fidedignidade e validade do inventário de depressão de BeckII (BDI-II) em adolescentes (Master's dissertation). Universidade Católica do Rio Grande do Sul, Faculdade de Psicologia, Brasil.

Queiroz de Azevedo Erse, M. P., Pereira Simões, R. M., Neto Façanha, J. D., Fernandes Alves Marques, L. A., Exposto Costa Loureiro, C. R., Teixeira Sampaio Mato, M. E., \& Pereira Santos, J. C. (2016). Adolescent depression in schools:+ Contigo Project. Revista de Enfermagem Referência, 4(9). https://doi.org/10.12707/riv15026

Ramnerö, J., Folke, F., \& Kanter, J. W. (2016). A learning theory account of depression. Scandinavian Journal of Psychology, 57(1), 73-82. https://doi.org/10.1111/sjop.12233

Rico, P. (2009). La Zona de Desarrollo Próximo. Procedimientos y tareas de aprendizaje. La Habana, Cuba: Editorial Pueblo y Educación.

Rodrigues, I. O., Freire, T., Gonçalves, T. D. S., \& Crenitte, P. D. A. P. (2016). Predicting signs of depression in children with specific learning disorders. Revista CEFAC, 18(4), 864-875. https://doi.org/10.1590/1982-0216201618421015

Rojas I. M., MINSAL, (n.d.). Atención de personas con Depresión en el AUGE. Retrieved 7 June, 2019, from https://www.minsal.cl/portal/url/item/71e7a5ac9b1dfedae04001 011f010680.pdf

Santos, J. C., Simões, R. M. P., de Azevedo Erse, M. P. Q., Façanha, J. D. N., \& Marques, L. A. F. A. (2014). Impacto da formação"+ Contigo" nos conhecimentos e atitudes dos profissionais de saúde acerca do suicídio. Revista Latino-Americana de Enfermagem, 22(4), 679-684. https://doi.org/10.1590/0104-1169.3503.2467 
Seligman, M. E., Kaslow, N. J., Alloy, L. B., Peterson, C., Tanenbaum, R. L., \& Abramson, L. Y. (1984). Attributional style and depressive symptoms among children. Journal of abnormal psychology, 93(2), 235-238. https://doi.org/10.1037/0021-843X.93.2.235

Tandon, M., Cardeli, E., \& Luby, J. (2009). Internalizing disorders in early childhood: A review of depressive and anxiety disorders. Child and Adolescent Psychiatric Clinics, 18(3), 593610. https://doi.org/10.1016/j.chc.2009.03.004 